International Journal of Philosophy and Theology June 2017, Vol. 5, No. 1, pp. 18-35

ISSN: 2333-5750 (Print), 2333-5769 (Online)

Copyright (C) The Author(s). All Rights Reserved. Published by American Research Institute for Policy Development

DOI: $10.15640 /$ ijpt.v5n1a3

URL: https://doi.org/10.15640/ijpt.v5n1a3

\title{
Eternal Immolation: could a Trinitarian coordinating-concept for Theistic Metaphysics solve the Problems of Theodicy?
}

\author{
Damiano Migliorini ${ }^{1}$
}

\begin{abstract}
The author contextualizes the Problem of Evil in Open Theism system, listing its main theses, primarily the logic-of-love-defense (and free-will-defense) connected to Trinitarian speculation. After evaluating the discussion in Analytic Philosophy of Religion, the focus is on the personal mystery of evil, claiming that, because of mystery and vagueness, the Problem of Evil is undecidable. Recalling other schools of thought (Pareyson: ontology of freedom; Moltmann: Dialectical theology; Kenotic theology; Original Sin hermeneutics), the author tries to grasp their common insights. One of them is the evident explanatory failure of theodicies, expressed in the antinomian statements 'God is not innocent'. The author follows these insights, developing the concept of Eternal Immolation (Bulgakov), arguing that, without a proper understanding of its mystery (what is, and what is not), theistic theodicy could remain compromised. 'Eternal Immolation' is considered consequent - or already present - in recent speculations, it stands or falls when we accept that these reveal some unresolved points in Christian doctrine. Hence, 'Eternal Immolation' becomes a coordinating-concept, able to bring together their assumptions: several kinds of kenosis, the ontology of freedom with a logic-of-love defense, strongly linked to a libertarian human freedom, and the acknowledgement of the unresolved mystery of evil.
\end{abstract}

Keywords: Evil, Atonement, Theodicy, Kenosis, Ontology of freedom, Original Sin

\section{Purpose and method of this work}

With this paper I will contextualize the Problem of Evil in the theoretical model called Open Theism, listing its main theses; I will summarize the ideas of other schools of thought (ontology of freedom and kenotic Trinitarian theology), in an attempt to grasp their common insights; at the end, I will try to assess whether the invoked perspective constitutes a promising path, and under which conditions, in particular with reference to the concept of Eternal Immolation. With reference to this concept I will refer to Sergej Bulgakov (2008), because of his extensive development of the topic. The paper is not conclusive, rather it tries to demonstrate a possible connection between concepts, and then suggests some paths which require in-depth study. The philosophical theses of Open Theism (OT) have already been widely discussed in the literature, especially those related to divine omniscience (Rissler, 2015). I prefer to focus on what we might call the "theological problems" that is, those linked to a specifically Christian theistic account (e.g.

\footnotetext{
${ }^{1}$ University of Verona (Italy). Personal mail: via Zanon, 32, 36050, Quinto Vic.no (VI), Italy. Email: damiano.migliorini@univr.it
} 
the personal God, Creator, perfectly good, omniscient, manifested by Christ) ${ }^{2}$. About the consistency of the proposed reformulation of theism advances by Open Theists, it has already been argued (Migliorini, 2014a) that, if it is true that OT responds to real theoretical problems - none of the "classical solutions" to the dilemma of divine omniscience and human freedom seem to be without critical issues ${ }^{3}$ - it remains metaphysically and epistemologically very weak. OT's theoretical proposal on evil is affected by this, and although it is not particularly innovative - it should be considered carefully because, starting from the problems it does not solve, interesting trails could be developed.

The space I have here does not allow me to analyze all the arguments accurately. Consequently, I proceed through some "theses", with very humble intent: I will show some theoretical path knots, the connections between some theses and, very briefly, the assessments about the progress still to achieve. For the list of theses and evaluations I will indicate some important texts in the footnotes. Obviously, these theses are a starting point, and they may be rejected. For the purpose of this work, I must admit them as plausible and shareable.

\section{The "theological theses" of Open Theism}

Let start with describing the point of view of OT - if there is a uniform one, accepted by the authors affiliated to this doctrine - regarding theological issues. The theses are grouped by topic:

Providence. (a) In line with the claims on dynamic omniscience, the open view does not consider the 'divine plan' for this world fixed or invariant from eternity; rather, the divine purposes are implemented in a dynamic historical context (Rice, 2004, 63-65). (b) OT distinguishes between: 1. the ultimate goals of God for the world; 2. the various courses of actions that He takes to reach them: God can only prepare a 'master plan' that goes from the instant of creation to the recapitulation of all things (e.g. the image of the ship described by Dante ${ }^{4}$. (c) God can know all the possible answers to all possible situations, but does not know in advance which of them will be realized in the real world (this claim is opposed to Molina's account $^{5}$ ). (d) The image frequently quoted in texts (Rice, 2004, 63; Sanders, 1998, 243) is the 'chess player'; it's a metaphor used to ensure that, despite the freedom of creatures and the indefiniteness of the future, God maintains control over creation ${ }^{6}$, but the play is not already decided from the start: God has only guaranteed his victory and He only decides the initial rules of the game (Sanders, 1998, 175). (e) God can sometimes decide by himself what will happen, but He usually changes his plan in order to accommodate the free decisions of the creatures (Sanders, 1998, 174). (f) It is clear that the OT rejects meticulous providence, because it would constitute a manipulative account of the human-divine relationship, while a general providence guarantees a personal friendship. $(\mathrm{g})$ in the 'risk model' God controls many things but not everything. This notion of a general providence has concrete impacts on the Problem of Evil, since it seems to be the most suitable (though metaphysically and theologically problematic) to guarantee real human freedom, interpreted in a libertarian way, that is, the central point in order to support a free will defense (Swinburne, 1998, 34).

Evil. (a) The existence of 'gratuitous evil' or 'pure evil' is under discussion, but in OT seems to be a well-founded starting position: there are events that we perceive as negative and which should never happen even if motivated by the virtue of greater good ${ }^{7}$ (e.g. the Holocaust, the death by starvation of an innocent child, the unnecessary suffering of animals, etc.; Dostoevskij, 2003). (b) OT provides a satisfactory solution to this problem, at least from the point of view of its supporters: Free evil exists in the world because God has granted man a freedom that can be transformed into evil. In keeping with this original creative choice, God does not intervene to limit the evil, in order to not violate freedom He has given to his creatures. In OT, then, it seems there is no intention of limiting the destabilizing range of 'gratuitous evil' (Pinnock, et. al., 1994, 168). (c) Sanders invites us to switch from a 'free will defense' to a logic-of-love

\footnotetext{
2 Beside these theses other "philosophical arguments" are implied (libertarian free will, A-Theory etc.) not discussed here.

${ }^{3}$ See, for example, Migliorini (2015a, 2015b, 2016a, 2016b).

${ }^{4}$ Dante Alighieri (2014, Paradiso XVII, 37-42); Roatta (1947); Businelli (1943).

${ }^{5}$ For Moreland-Craig, the Molinist account of providence is still the best we have (Moreland \& Craig, 2003, 565).

${ }^{6}$ Geach, 1977, 58; other similar analogies: theater director, the leader of a roped part (Sanders, 1998, 229).

${ }^{7}$ «We must not regard the evil that occasions something good as anything less than evil in itself» (Rice, 2004, 71).
} 
defense, according to which evil is a contraindication of a choice of love that is expressed in the creation of free human beings with whom a relationship of true friendship is established (this is the main condition for the idea of 'best of all possible worlds', the best creative choice) (Sanders, 1998, 268). God is responsible for the ontological and moral structure of the world, but not for individual actions. (d) about 'natural evil', OT refers to the classical theory: the ontological structures of today's world enable the existence of goods and - collaterally - evils, as imperfect. In this picture, the assumption that we live in the 'best world' "creatable" (that can be create) remains a plausible statement ${ }^{8}$.

Original Sin. (a) For OT there is no alternative: if the sin of Adam and Eve was preordained, they are not the real culprits of that sin, but God was the mastermind behind it. The only acceptable answer, then, is to consider Adam and Eve as really free creatures, perfectly able to be right or to be impious. (b) Their sin is derived from their human nature, limited and endowed with freedom, and is therefore attributable to them; Adam and Eve were not perfect in origin (and consequently a 'paradisiacal state' is a narrative fiction): they have been created imperfect, that is, potentially sinners.

(c) to be humans and to be creatures they must be created imperfect in will and intellect; (d) the story of Adam and Eve is a myth which explains the original ontological structure of every human, who is called to the earthly paradise, but prone to make mistakes and sins by virtue of the original choice of God to create him with free will, and responsible for his own choices.

Predestination and Grace. (a) Sanders highlight the fact that, if God can express his justice just in saving someone and condemning others, then God is in some way dependent on the damned for the completeness of his nature. On the contrary, Sanders claims, God loves every man, but this 'love' does not eliminate the possibility that some people may throw themselves out the love relationship, by their own will (Sanders, 1998, 253). (b) The reprobation, from this point of view, it is the respect of a conscious decision of a creature. Sanders, then, introduces the concept of conditional election: God consents to be affected by the actions of humans also as regards their election (Sanders, 1998, 253-56). (c) For the idea of 'salvation' to be meaningful, God needs to be personal, and love is not required on our part: we must choose to enter into this relationship of love that involves salvation (Sanders, 1998, 256). (d) If man has a free will in a libertarian sense, therefore, there does not have to be an efficacious grace, coercive, unalterable and irresistible. There can only be a sufficient grace, that is a God's antecedent decision to enter into a relationship with humans and a natural openness of man to seek communion with God'. (e) Thus, an 'irresistible Grace', according to Guy, is an oxymoronic concept, because, with this kind of grace, creation would become an infinitely complicated and intricate puppet show ${ }^{10}$.

Trinity. (a) According to OT, John's affirmation «God is love» is crucial, because it «allows a dynamic understanding of God as He is in Himself» (Rice, 2004, 40). This "dynamic" interpretation, hence, is indebted to the Trinitarian speculation. (b) According to Pinnock, the doctrine of Trinity «is relevant to the openness of God because the social Trinity is an open and dynamic structure. It does not portray God as solitary, domineering individual but as the essence of loving community. [...] The Trinity points to a relational ontology in which God is more like a dynamic event than a simple substance and is essentially relational, ecstatic and alive. God exists as persons united in a communion of love and freedom» (Pinnock, et. al., 1994, 108). (c) The loving relationship, therefore, in this view, is not only external (between God and man), but it is internal, constitutive of God himself. This statement avoids to affirm the necessity of creation. (d) God is self-existent and independent of the world, even though He has decided to create it due to an abundance of love and a free choice. (e) These ideas open some perspectives on the perception of God as necessarily Trinitarian, also from a philosophical point of view. The challenge is to rethink the dogma of the Trinity philosophically, and think about the essence of God as "love" and "Trinity" regardless of Revelation (Alston, 2002; Migliorini, 2014b).

\footnotetext{
8 Sanders (1998, 274); Basinger, (1991); argument that seems to converge with Swinburne's one (1998), who lists in many chapters some goods, trying to show how they can't occur except by producing collateral evils.

9 Defined by Rahner as 'supernatural existential' (Rahner, 1965b, 44-77).

10 Pinnock $(1995,45)$. The Grace looks like a dance between two «personal partners» (Sanders, 1998, 257).
} 


\section{The Problem of Evil in contemporary Analytic Philosophy of Religion}

In Analytic Philosophy of Religion the debate on this issue is quite dated and has involved many authors. Among the best known, we can remember Mackie ${ }^{11}$, Swinburne, Inwagen, Geach, Plantinga, Tooley, Rowe, Pike, McCord Adams, Davies, Howard-Snyder, Bishop and Perszyk. Among the classics, who have been referred to and "updated" by contemporary authors, we can clearly include: Plotinus (1991), Augustine $^{12}$, Anselm (Rossi, 2000), Aquinas (Savino, 2000; Galeazzi, 2014), Leibniz ${ }^{13}$, Kant (Fiorini, 2000; Fremstedal, 2014) and Hume (2007). To outline all the positions, arguments and counter-arguments is beyond the scope of this paper. I move directly to an overall evaluation.

First of all, I think it is necessary to focus more on what Gevaert calls the personal mystery of evil: «Seeing the problem of evil only on the universal scene [...] basically means to falsify it. The problem of evil arises also essentially from the fact that every human being, in his unrepeatable uniqueness, is hampered and blocked in his fulfillment. Here there is a personal mystery of evil because every human being, even if he actually belongs to different forms of totality, is never radically reducible to some totality» (Gevaert, 1992, 210). Looking at this mystery from the point of view of existentialist, every rational explanation is shipwrecked. This is not an emotional matter, or a problem of "consolation": there is an evident contradiction between an undeniable infinite human dignity and the fact that it can be sacrificed for "the best possible world" or any other explanation.

Bearing in mind this consideration - and referring to the above mentioned lively debate - in a final balance we could say that the problem of evil remains fundamentally "pending" for at least three reasons: (1) We don't have a grounded account of free will in the libertarian sense, nor evidence against it. We postulate the existence of a libertarian free will, but we can not ground $\mathrm{it}^{14}$.. This means that the logical problem of evil, which is resolved only if the free will defense works, remains pending because the notion of libertarian free will is obscure ${ }^{15}$, and mediation with an universal (mysterious) divine causation is baffling too: as far as human freedom, omniscience and divine causation we do not have an unambiguous, universally accepted definition. (2) The argument of Leibniz regarding a God who "must have good reasons" (otherwise the world would not exist), is based on external and fideistic assumptions (e.g. the creation, or the existence of a good God) (Leibniz, 1952). As noted, Leibniz's argument works only if we assume that God exists, but this is clearly circular: if God exists, the world is the best possible one, but the world is the best possible because God exists ${ }^{16}$. This circularity is a rationally plausible solution but is not entirely convincing: Leibniz's argument, whilst sufficient to exclude the existence of 'gratuitous evil', is unsustainable on a personal level. (3) We do not know "how much" evil there is in the world, because we never have access to the totality (past and present); also because - potentially - even eternal life should be included in the calculation, and this seems rather complicated. The epistemological argument (Hume, 2007) seems to me to be effective, and can be overturned only by accepting certain premises of faith. Thus, the theistic model is consistent, but fundamentally undecidable: we do not know if the world is the best and when and if God intervenes ${ }^{17}$ (we should have knowledge of the "Whole"), and if the man is truly free (if a sense of "truly" is given, in the case of freedom).

In conclusion: mystery and vagueness mean that the Problem of Evil is undecidable - I agree, here, with Inwagen $(2006,106)$ - and therefore is completely unusable in the dispute between atheism and theism: the Problem of Evil is not a problem, in the sense that it does not affect the decision to believe or not in

\footnotetext{
${ }^{11}$ Swinburne (1998); Inwagen (2006); Mackie (1955); McCloskey (1960); Plantinga (1974a, 1974b); Howard-Snyder \& HowardSnyder (1993); Rowe (2001, 1986). Some texts for a summary: Peterson (2010); Oppy (2010); Moreland \& Craig (2003); Davies (1993); Hick (1967); Pike (1963); Tooley (2015); Stump, (2010).

12 Hick (1967). The Augustine's account of evil as privatio boni is assumed also by Guardini (Gerl Falkowitz, 2005).

${ }^{13}$ Leibniz (1952); Murray and Greenberg (2016); Jorgensen and Newlands (2014).

14 The problem, for the free will defense, is that no satisfactory formulation of what the free will is (in the libertarian sense) has ever been given (Tooley, 2015, par. 7.2).

${ }^{15}$ De Caro (2004); Inwagen (1982); Stump (2001); Chiereghin (1991).

${ }_{16}$ Pike $(1963,190)$ : in other words, the world exists, then it is the best, because God has to create only the best.

${ }^{17}$ We don't know if God intervenes in the world, how much and when, or whether it is required to Him to do so, or if He can do it (consistently with His immutability, eternity...). Of course, if God intervenes too much in every difficulty, would not exist many human goods, such as responsibility for our actions (and virtues), the satisfaction of having achieved a goal, and so on (Hick, 1967, 475), but this does not imply that God can't intervene in serious situations.
} 
God. It can not be used to support atheism but, at the same time, remains an open question for theism. The Problem of Evil is, to a great extent, a matter of hermeneutics - how we interpret certain facts, whether or not from the point of view of the Whole (Pike, 1963, 189) - and perspective: if my attitude towards reality is positive (that is, if I think it is positive that a fact "is") this evil (whatever it is) must have an explanation, since the existence of the world is good (and rational). It does not matter whether we do not give such an explanation: it will be there somewhere. What now I propose to do is to gather some insights and try to encompass them within a category, Eternal Immolation, which I will try to outline. Discussing it may prove to be ineffective or useless, compared to the role - rather ambitious - that, again hypothetically, it could take in a theodicy. But I'm convinced that it is a theoretical path that we can try to traverse, by discussing it in depth.

\section{Alternative paths: Pareyson, Moltmann and Kenotic Theology}

The common modern sensibility towards the failure of theodicies (Pastrello, 2000, 263) has led many authors to think about alternative paths. The echoes of that failure emerge in literary (Dostoevskij, 2003; Mounier, 1950), philosophical (Jonas, 1987; Ricoeur, 2007) and theological works (Moltmann, 2015). In these descriptions, evil reveals an infinitely negative character, both qualitative and quantitative, deploying its effects throughout history (Ciancio, 2006, 41). Evil is what it was not to be: those who perceive evil as something unjustifiable assume, implicitly, that at the origin of that evil there is a fault, which perhaps may even be God's fault (Ciancio, 2006, 38-42).

The failure of the reconciliation between God and the existence of radical evil has become the predominant challenge of 'metaphysical reason' that constitutes the structure of theodicy; theodicy is possible only with the premise that reason is the meaning of totality (Pastrello, 2000, 261-73). One attempt at a "metaphysical update" of Christian Theism ${ }^{18}$ - without that premise - is the one developed in the speculation of Luigi Pareyson ${ }^{19}$, an influential Italian Schellingian author ${ }^{20}$. Again, it is not possible to describe this thinking here, but I would like to recall at least some basic theses of his ontology of freedom ${ }^{21}$ : (I) "Being" (God) is freedom and abyss, originally dialectical; (II) In the abyss of human evil there is an even deeper evil, ontological, eternal, pre-existing, which resides in the abyss of God's freedom. Somehow, evil is included in God; (III) The positive in itself (Being) is the victory over evil (Nothingness), what ab aeterno won: the Beginning-God has an inherent dialectic, that is unthinkable except as containing in itself evil as something that has been defeated; (IV) 'Being' and 'Good' are not fundamental, but dependent: they are "hanging" on to freedom.

Thus, only the ontology of freedom reveals itself as an appropriate description of Being, not the concepts of substance; (V) There is an inseparable link, then, not only between God and evil but it is also necessary to state that God is not innocent, in respect to evil. God is conceivable as containing evil in itself, although evil has already been overtaken and defeated in positivity; (VI) the suffering of God is the only answer that can be given to the problem of innocent pain. Christ introduces suffering in God: humankind is freed from suffering because it is experienced by Christ in God and, in Him, made infinite (it is the cry of Christ on the Cross). Suffering becomes a matter between God and God. Clearly, there is a transition from the ontological level (the Non-Being which was defeated) to the moral level (God acting 'wickedly') and to the eschatological and Christological level. Not only does God triumph over evil, but also seems to 'perform' it to Himself and, simultaneously, redeems it, just as one of His sins; (VII) God suffers the pain triggered by man, turns against Himself the anger reserved for the sinner, He appropriates all the sins of man as if He had committed them. Here, the philosophical idea is that Christ - the innocent, sent by God and God Himself - has voluntarily taken upon himself the sins and sufferings, in solidarity with sinners, up to even feeling the abandonment of the Father. Again, the paradox: God is both a sinner (He is responsible for the sins of man) and an innocent (He is not committed to them). For this reason He expiates for 'his' faults and those that are 'not his'.

\footnotetext{
18 About the "classical theistic metaphysics" I refer to Kretzmann (1997).

${ }^{19}$ Some of his main works translated in English: Pareyson (1995, 1971). A biography: Tomatis (2003). In Italy, the Schellinghian school, which is descended from Pareyson, includes numerous philosophers (Limone, 2013, 11-56). Some examples: Cacciari (1990); Tomatis (1994, 1995, 1997); Ciancio (1989); Coda (2003); Donà (2008).

${ }^{20}$ Pareyson interprets the second Schelling, who draws greatly on Bruno and Fichte. For an overview of Schelling's Trinitarian speculation: O'Regan (2011).

${ }^{21}$ All of the following eight points are taken from Di Napoli (2000, 247-61).
} 
Clearly, «the evil in God» is an elliptical expression: God remains "positive" even if He contains the possibility of evil, that is, the rejected alternative. In this apophatic proceeding, we are definitely immersed in the mystery of a God who is the origin of evil in the sense that, at the same time, He triumphs over it and establishes it as a possibility. The ontology of freedom (of which is an integral part the speculation about evil) arises from the need to confer on God a certain idea of freedom as a divine attribute. The thesis of «God before God», also starts from the Kantian reasoning on the unconditional (Kant, 2003: The Ideal of Pure Reason). Evidently, we can rule out as meaningless the idea that God could 'not be', perhaps radicalizing the ontological difference between God (and his freedom) and us, but in this way, talking about God, the terms 'freedom' and 'necessity' would overlap, and we would fall into other aporias. The ontology of freedom is an attempt to take certain data and theoretical consequences into account, while classical metaphysics tends to neglect them. Rather than being over critical of Pareyson's speculation, we should understand it as the other side of our metaphysical paradoxes. There are aporias, indeed, even in the classical doctrine of God (we might refer to this as Thomistic), as there are in Pareyson's one. We have to understand what we want to sacrifice from time to time, throughout the history of thought; because something must be sacrificed. Evidently, when evil is regarded as real, something that should not exist, the rational systems lose their significance, and they are converted to a narrative philosophy (like Pareyson's) with the predominance of myths poetic interpretation, which coincides with the consciousness of the impossibility of a definitive capture of truth (Di Napoli, 2000).

The book The Crucified God of Moltmann (2015), which incorporates many of Barth's insights (Cerasi, 2006) is emblematic of the abandonment of classic theodicies and the onto-theology of theism. According to Moltmann (2015): (I) Christian theology, because it is a theology of the cross, is a critical theology, a theology that no longer pretends to be the "true philosophy": is a crucified theology, which distances itself from the philosophical theology, in order to be "true theology", that is, dialectical theology. (II) A theology after Auschwitz is impossible, or sounds blasphemous to those who "make do with" theism. (III) A 'theology of the cross' is not able to offer any theistic answer to the problem of the dying Christ, and therefore of evil. If it did, it would empty the cross. But we can not even give an atheistic answer. God's being is in suffering, and suffering is in the essence of God, since God is love. This is a 'metaphysical revolt' that does not accept easy rational settlements. Faith, which comes from the event of God on the Cross, does not solve the problem of suffering in theistic terms, stating 'why' this pain should be like it is.

Theses similar to Moltmann's (we can identify them as the common ground of dialectical theology) are now very common and widespread ${ }^{22}$, with different points and arguments, but mainly related to those mentioned above. How should we assess them? We can divide the evaluation into two main areas: 1. From the metaphysical point of view, Pareyson's and Moltmann's settings (and for large part OT's) are full of aporias; the descriptive philosophy - and, with it, the dialectical theology - can be comforting, but is reduced to a problematic apophaticism, because it refers to a mystery that can only be accepted in a fideistic context.

It is also true that these settings arose from real unresolved issues in theism, and therefore must be taken into consideration as being plausible. 2. From a human (existential) point of view, we may wonder how it could be useful, for us, to know that God suffers with humans ${ }^{23}$. It is really a meager consolation, 'pathetic' from the human point of view, and desolate from the theoretical one. It seems that, in the end, God's "accompanying" us in our suffering can have meaning only if God guarantees a victory over evil and suffering. The archetypal and the final victory, however, can only be guaranteed by an omnipotent God in the classical sense, or affirmed by faith (and then, we come back to the starting point).

A third theological path, that could be connected to the previous ones, is the kenotic theology ${ }^{24}$, which intersects the discussions about divine immutability and impassibility ${ }^{25}$ (knowing its main points is a preliminary step to reading the next part). The term 'kenosis' can indicate various 'types' of kenosis (Brito,

\footnotetext{
22 For example in the 'anatheism' proposed by Kearney (2011).

${ }^{23}$ Charamsa (2003) wonders if this is a valuable way: how "useful" could a God who suffers with us be?

24 About Theologia Crucis: Toniolo (1995); Richard (1982).

${ }^{25}$ Charamsa (2002); Küng (1972); Mühlen (1974); Scheffczyk (1998); Hauke (2011); Creel (2010); Leftow (2012); Pawl (2012); Wainwright (2012).
} 
2006): intra-divine, of the Son (redeeming) ${ }^{26}$, creative and immanent ${ }^{27}$, revealed. The first is the eternal generation of the Son, understood as archetypal kenosis (primordial or 'eternal kenosis') ${ }^{28}$, and is the 'space' for all others. This kenosis, which is based on the altruism of the divine persons (Balthasar, 1971, 195), is the very image of the Trinitarian God of love, where the Father does not restrict the divine being to himself, but He gives it, transmits it to the Son like an explosion of love. Is a kenosis internal to the divine nature, like a kenotic self-denial which is absolute love (Serretti, 1998, 39, 86). This activity of self-emptying is the perfect love, or agápe, which is the very nature of God (Mitchell, 1991). Secondly, it demonstrates that eternal kenosis (biblical category) can be also interpreted as the moment of Non-Being (philosophical category) in divine life: Non-Being coincides with the category of 'donation' and 'annihilation' (Coda, 1987, 387). In this dynamic of donation, the Father properly 'is not', has existence, not even that of Being. This is the "Cross in the Trinity", the God's complete immolation, of which the Cross of Christ and his sacrifice are revelations. As a coincidence of Being and Non-Being, as the source of Being, the Father is in fact Silence, 'God before God' (Panikkar, 1975).

The main problem with this approach is that a 'totally kenotic' God is inconceivable ${ }^{29}$; however, to think about Trinity, we are to some extent "forced" to assume that divine nature is kenotic ${ }^{30}$, provided that, in the absolute forgetfulness of the Self for love in freedom (this is the correct notion of intra-divine kenosis), there is the recovery of His identity (Staglianò, 2003, 158-59). In this perspective it is appropriate to distinguish between a 'kenotic principle' and an 'agapic foundation' (Lorizio, 2006): the self-giving is the beginning (way of being or acting) of God, which coincides with His essence (being Love) and constitutes its ontological foundation.

The OT authors also tend to use the concept of God's self-limitation, self-restraint or self-control (Sanders, 1998, 241), to make plausible 'dynamic omniscience', the Trinitarian account of God, as well as the 'logic of love defense'. Once again, therefore, we are dealing with the obvious convergence of movements of thought which are distant from each other on the surface. Resonances and affinities between Moltmann, Pareyson and some OT's theses are evident ${ }^{31}$, and they have in common the attempt to address the Problem of Evil without resolving it: against any rationalization, the "solution" proposed is to assist the person who suffers with a suffering God (we can call it a Christological perspective). The problem of pure evil and the libertarian interpretation of free will, are the two conditions that lead the OT to review classical theism, and that lead it to come very close to the other schools of thought we have examined.

Up to this point, the patience of accepting the series of conclusions of all these schools of thought (as interpreted here) has been required, because it is in them, taken together, that the picture of the whole emerges. Although each of the theses can be criticised, the 'whole' of them is a shared feeling that deserves to be considered as plausible. Even the acceptance of explanation capitulation is a conclusion on which we may not agree, but, hereafter, I must take it for granted.

\section{5. «It is impossible to turn Adam into a concept»: the importance of Original Sin in the development of a theodicy... and the aporias of the myth}

\footnotetext{
26 Usually, kenotic views focus on Christ's kenosis (Murray \& Rea, 2016); Davis (2006) addresses kenotic Christology.

27 Polkinghorne (2001). An important exponent of this theology is precisely the Orthodox theologian S. Bulgakov who expressed this view in the book The Lamb of God (2008). See also: Coda (2014, 1998), O'Donnell (1995), Zak (2007).

28 We can interpret the eternal generation as a way of thinking about an eternal becoming in God, in a movement beyond the ousia, an Eternal Beginning were the Father decides to be a Father (Tomatis, 2007).

${ }^{29}$ Balthasar $(1971,189)$ noted that the kenosis can't be an all-embracing concept, because the essence of God isn't kenotic in itself (Coda, 2011, 475). Moreover, that even the kenotic theology is largely apophatic is clear to everyone.

${ }^{30}$ Bulgakov makes a distinction between nature and glory: God can lose the second (the relative attributes, e.g. omniscience) but not the first (the immanent attributes, such as love, holiness). See: Gavrilyuk (2005, 260-61).

31 We could also add some insights of Process Theology and Agatheism (Salamon, 2015). The connections between Process Theology, Open Theism, Kenotic Theology, Trinitarian speculation and Panentheism are known (Clayton, 2005). According to Clayton, the connection between Process and Orthodox theology is given by Panentheism, but transcends it. According to this author, OT is a mid-way between the theology of the process and the classical theism, and the hypothesis of Clayton is to accept a process position while admitting a creation ex nibilo. Such mediation is made possible precisely by the Trinitarian theology, especially in its kenotic version, which allows to correct Panentheism in part.
} 
The doctrine of Original Sin has always been an integral part of Christian theodicy ${ }^{32}$, even though the history of the interpretation of Genesis has been quite difficult, and is still open (Sanna, 1994, 187-89). Today we see a renewed attention to this myth, perhaps also due to the perceived failure of rational explanations: we must pay attention to the myths, Ricoeur (2007) reminds us, especially those which "explain" evil, because they allow us to think beyond the objectifying categories ${ }^{33}$. Also the theological debate, during the past century, has had a considerable revival, in parallel with scientific discoveries: many theologians have proposed new interpretations of the doctrine ${ }^{34}$, and also some analytical authors have stressed the importance of it ${ }^{35}$.

For our purposes, however, is sufficient simply to emphasize a few points from this rich, complex doctrine: (I) 'Original Sin' speaks about the experience of a mysterious solidarity in which «each person, is both victim and culprit. Victim, because he enters in the world already marked by an objective negativity which will affect him, guilty because he immediately becomes an accomplice and he increases, to a greater or lesser extent, the weight of this global illness of humanity» (Grossi, et. al., 1997, 229). (II) With this doctrine, Christianity recognizes that the 'sin of the world' expresses the radical orientation of humankind, which, however, is neither totally corrupted nor lost ${ }^{36}$. (III) The myth holds that God created a perfect world, which is then spoiled by the rebellion (concupiscence, death, suffering, work: Ricoeur, 2007). This is important for theodicy: God could create a better world (and He did so, if we believe that He created the Garden of Eden ${ }^{37}$ and therefore, the originating sin is inserted in the doctrine precisely to exonerate God from being the author of moral and physical evil (the originated sin). (IV) The doctrine of a historical Original Sin, hence, has the function to justify the fact that God could create a heavenly world (which $\mathrm{He}$ did), but in the end He wanted (or allowed) the world to be turned into the fallen form. Or, paradoxically - in a symbolic-ontological interpretation - Original Sin allows us precisely to deny that God could create an earthly paradise (the perfect world): create a paradise of free people (Adam and Eve).

This means, in fact, accepting that this paradise might not endure (because a limited and free person sins, sooner or later). (V) Today, however, we do not admit that Original Sin is a transmission of fault (Sanna, 1994, 201) or, at least, in an analogical sense). On the other hand, it is true that the 'lack of Grace' (which requires baptism in order to heal ${ }^{38}$ ) occurs only if there is a personal-fault ${ }^{39}$. Thus, the guilt of Adam becomes, for his descendants, concupiscence, that is a sin of nature (imperfections and weak will): humankind loses justice and holiness, even if concupiscence is only a predisposition to sin, and not a sin. Original Sin is therefore the historical beginning of a situation of dis-grace (Sanna, 1994, 194, 199) and, in this writhing of the aporia and of dogmatic definitions, we understand why the idea of Original Sin is, at the same time, fundamental and destabilizing for theology. (VI) Last but not least, if Christ saves all humans from sins, then the origin of His coming in the world must be a real fault ${ }^{40}$, that is, a personal moral act. Otherwise, Jesus would not save man from sin, but would only repair a mistake made by God the Creator (Sanna, 1994, 194). What we will wonder, talking about Eternal Immolation, is whether things are exactly like this: Christ saves every man from personal sin, not only from Original Sin; He did not died on the cross to fill the gap of an insufficient creative choice (this is a logical necessity!) by God the Creator, because this is somehow expiated by God himself. Contrary to the claims of Geach, the reinterpretation in a symbolic

\footnotetext{
32 For example Kant had a rationalistic account of Original Sin (Ferretti, 2009).

33 Paying attention to a myth means not utilizing it to justify philosophies which have already been decided (Fabris, 2014).

${ }^{34}$ To remember the most famous: Maldamé, Basset, Schoonenberg, Theilard de Chardin, Nemo, Baumgartner, Köster, Vanneste, Villalmonte, Haag, Baumann, Weger, Eichinger, Flick-Alszeghy, Rahner, Pannenberg, Ritschl, Rondet, Dubarle, Alison. For a critical discussion: Gibellini (2016, 135-44); Scheffczyk (2012, 374-77); Ubbiali (1996, 9-60).

35 Swinburne (1998, 37, 106); Quinn (2010); Geach (1977, 84-102).

${ }^{36}$ Coleman (2013): against the hypothesis that we are changing our nature for the better (secular optimism), he argues that 'the desire to outdo itself is part of human nature, and that it has been described with the doctrine of Original Sin.

${ }^{37}$ However, if God could create a world (the Heaven) which is more perfect than the present one, in which there was the beatitude and freedom, then the argument of the 'best of all possible worlds' becomes incompatible with Revelation.

38 Did Christ change human nature by His sacrifice? Probably yes. But why would God created us imperfect to perfect us then? To answer this question, it is necessary to think of the Eternal Immolation. Without it, the 'perfection accounts' (cf. footnote 56) it seems to me problematic, just as the doctrine of infant baptism is problematic. The 'perfection account' hints at something which is correct, but must be integrated and 'moved' in an eternal perspective.

${ }^{39}$ Sanna $(1994,193)$; the doctrine, positively, says that the current situation of existence is historical (Ubbiali, 1996, 27).

40 A concern expressed for example by Antonio Rosmini (Gomarasca, 2009, 753).
} 
key of the Original Sin doctrine (not a radical denial of it) does not compromise the needs of redemption in Christ ${ }^{41}$ (incarnation and resurrection).

However, in the intuition of Geach $(1977,88)$ - which was already present in Pascal (Ciancio, 2009) - the Original Sin doctrine is founded on partial intelligibility. The myth creates numerous short-circuits, and can be accepted in all its content only by paying the price of recognizing its mysteriousness: «It is impossible to turn Adam into a concept (Grossi et. al., 1997, 23). We might admit - in its theological, redemptive implications - that originated sin is the only way God could create creatures (is a logical necessity) and that God might in part be "guilty" (together with the creature), because, as we have seen, God could have 'not-created' (or could have created a paradise), and thus preserve the 'state of better things' (which is Himself in his splendid isolation and perfection) ${ }^{42}$. But God decided to create a not-paradisiacalworld, when He could have abstained from doing this and saved us from a lot of trouble, and then $\mathrm{He}$ accepted partial blame for this choice, which is incomprehensible. The incomprehensibility of this choice is expressed by the myth with a transfer of fault from God to Adam: it is a way of excusing God, but the attempt is not credible at all. Adam is the incomprehensible 'hand of God'43, is his "stunt man" (it is God himself, the God who creates freely without reason, acting like a man!), introduced in order to narrate - or hide with a human mask - what can't be explained or said about God (his guilt).

The 'Personal Historical Original Sin' of Adam is the story of the incomprehensibility of a situation, a story of translations of an incomprehensible fault. Is not an explanation. The theological challenge, therefore, is to understand that creation and salvation are one act, even if in the economy of salvation they appear to be consecutive. According to Christian doctrine, God created in Christ and with Christ (Bianchi, 1990, 13-20): accepting that Christ is the beginning and the end of creation implies an understanding that Grace can not be reached "after" creation, but must be contemporary with it, because creation is already Grace, because it is already in Christ ${ }^{44}$. We will try to respond to this challenge in the paragraph about Eternal Immolation, trying to develop the intuition that God starts creative work bearing in mind the mystery of the Sacrificial Lamb, who is then an essential aspect of the creative depth of God (Alison, 2009, 40-41).

\section{How can we interpret the Eternal Immolation?}

\subsection{What is Eternal Immolation}

The common insight is that, to get out of the doldrums of the Problem of Evil, we must try to realize a new philosophical and theistic view of God, perhaps from Trinitarian and kenotic metaphysics. Only here can the "Logic of Love" and the "incomprehensible fault" find its adequate placement. We will try, therefore, to follow this insight, looking for the development of an appropriate concept of Eternal Immolation (EI), a term that is not very common, although we can find some traces ${ }^{45}$, that we can ascribe to Bulgakov ${ }^{46}$. I do not present an analysis of the work of this author, but I will quote in the footnotes the text in which, in my opinion, the conceptual content that I will try to set out emerges. The context in which Bulgakov's kenotic theology is developed has been widely described ${ }^{47}$, as its aporias are well known. What I propose to do is simply to put the emphasis on one of Bulgakov's intuitions, which is usually neglected, and show its potential. What I would try to argue is that without a proper understanding of the EI's mystery, the doctrine of Original Sin and the whole theodicy could be seriously compromised, but at the same time, the concept of EI respects "the silence" that the problem of evil imposes on us. By EI, therefore, we can

\footnotetext{
${ }^{41}$ Geach claims that the denial of Original Sin makes Redemption vanish, so would reject Christianity (Geach, 1977, 98).

42 To create, for a perfect good God, was not the best thing to do: He must atone for creating (Ferrier, 1966, 33-35).

${ }^{43}$ If these insights are correct, Adam is not humanity, as claimed by Ricoeur (in La symbolique du mal, the second volume of Finitude and Culpabilitê). Adam is God himself, in His contradiction.

${ }^{44}$ This hypothesis has been developed at length by Alison (2009).

45 In his texts Bouyer $(1988,190 ; 1978)$ the eternal sacrifice of the Lamb is seen as the beginning of creation. We find the expression also in Durwell (1999, 93, parag. God the Father and Death). Some insights that go in the direction of eternal immolation in Moltmann (2015) where the cross is part of the Trinitarian history.

46 «This eternal immolation is the foundation of the cross of Golgotha for the salvation of the world» (Bulgakov, 2008, 338). I use Eternal Immolation (that I take from the Italian translation) instead of pre-eternal sacrifice (in English translation) because it expresses better the concept, and because we avoid using a term (sacrifice) that has been the focus of extensive diatribes. Also Gallaher $(2016,103)$ uses 'eternal immolation'.

47 About Bulgakov's Trinitarian account: Vallier (2000); Gorodetzky (1938); Gavrilyuk (2005); Papanikolaou (2011).
} 
understand, at least, three things: (a) the kenosis of the Father (ontological); (b) the kenosis of the Son (moral) for the Sin, that is, the redemption of original sin (from everlasting); (c) the kenosis of the Son (moral) for the sins (all of them, even personal ones: is the historical Cross). According to Bulgakov, I use the term EI, in addition to kenosis, because I want to emphasize more strongly the aspect of redemption (then b. and c.) and the connection with the issue of sin and evil.

If there are various forms of kenosis, moreover, allegedly there are also different forms of "redemption", at least two: (1) the redemption of creation: the redemption of existing evil, of the non-sense (the "incomprehensible fault"); (2) the redemption of human being, that is, the redemption of evil committed by him because of his freedom. There is a sort of reciprocal implication, as we have seen, between these two forms of redemption. The structure of creation is involved in the human ability to sin and, at the same time, many of the senseless sufferings present in creation are caused by part of that creation itself, man. Consequently, EI will be a Christian "response" to both requirements. If, however, there are three immolations, in which way, in God, the ontological moment (kenosis) and the moral one (atonement) are they coordinated? Why must the redemptive sacrifice be eternal? We have already given a provisional response analyzing the thought of Pareyson and the aporias of the doctrine of Original Sin: for God is not innocent (Di Napoli, 2000, 210).

At this point we feel the need to introduce the oxymoronic concept of EI, which must say something more about the intra-divine and creative kenosis. The EI of the kenosis of the Son is an oxymoronic term that we introduce to emphasize the sacrificial, redemptive and liturgical aspect: God Himself atones for his guilt, His fault for not intervening, when He could certainly have done so, and the guilt for having created, when He could have refrained from doing so. It is the mystery of this creative choice that is accountable to Himself 48 . Yes, it is perhaps quite irrational to think of "a sin in God"49, but is the consideration of the reality and the "personal mystery of evil" that forces us to do so. Is it God, then, who asks for forgiveness...but, how? The notion of EI tries to give an account of it, alongside historical immolation, in which 'Christ redeems the sin of God'.

This paradoxical formula is inevitable, it is an answer to the brothers Karamazov: in the two immolations (eternal and historical) God apologizes for the "tremendous harmony". The idea, then, is that Original Sin and its redemption are to be seen together, and have always taken place in the mind of God.

Alongside EI there remains the need for forgiveness of personal sins ${ }^{50}$ because it presupposes man's similarity to Cain, that is a part of the meaning of the Original Sin. This avoids a drift toward Pelagianism: the "fallen situation" of man is not remedied by EI, but assumed and accepted as inevitable ${ }^{51}$. However, EI expresses an intuition: God knows that, as a result of human imperfection, He should charge him with many sins, and destine him for damnation; therefore, to avoid an empty Paradise and an overcrowded Hell, God is aware that He must ignore a strict law of retribution.

However, in Christian doctrine, redemption (of God or man) is related to the event of the Cross. How should we then re-interpret it in the light of EI? In order to do this, we would need (the points are put as hypotheses for further work): (a) an adequate notion of incarnation, which assumes that also human flesh participates in the theandric pericoresis (in the Trinitarian kenosis) 52 ; in the incarnation, humanity

\footnotetext{
${ }^{48}$ « $\prod \mathrm{n}$ order to make it possible to pardon the sinner, God takes upon Himself the satisfaction of Divine justice for human sin. It is as if God, in the Holy Trinity, speaks once again in the Divine Counsel concerning man: Having created man, changeable in his creatureliness and now fallen, let Us recreate him, taking upon Ourselves the satisfaction of justice. This justice consists in the fact that the Author of man's being takes upon Himself the consequences of His act of creation - that is, the possibility of sin that has become a reality. God tells His creation: You are created by My hands. [...] And, since I am responsible for you, I take upon Myself the responsibility for your guilt. I forgive you; I return your glory to you, for I take your sin upon Myself; I redeem it with My suffering» (Bulgakov, 2008, 365).

49 The idea of a "fault" of God does not arise also from a deductive process: if God exists and is free to not-create, his solitary and perfect existence is (necessarily) the state of perfection is already the definitive victory over nothingness.

50 Swinburne $(2013,362)$ reminds as that atonement has necessary elements: repentance, apology, reparation and penance.

51 «The Incarnation is the salvation of the world not only from its creaturely relativity or changeability, but also from sin. That is, the Incarnation is reconciliation and redemption. In fact, its first goal is to eliminate the evil consequences of the bad use of creaturely freedom, the consequences of the Fall, and to restore the fallen Adam» (Bulgakov, 2008, 345-46).

52 Mazza $(2008,114-155)$ goes so far as to speak of embodied pre-existence; for a synthesis of old and new solutions (especially in the field of philosophy of religion): Marmodoro and Hill (2014).
} 
becomes the humanity of God, but already in the act of been created, humanity was assumed by the Logos: humanity could be considered as already participated in $\mathrm{Him}^{53}$; if the body of Christ is mysteriously always and forever in God, then, the body is always dead and resuscitated, and is also immolated eternally ${ }^{54}$. (b) An adequate understanding of the Cross. The four classical perspectives (Anselm: legal-satisfactory; Abelard: subjectivist soteriology; Thomas: redemptive or soteriological and thesis about convenience ${ }^{55}$; Duns Scotus: perfective or Christological ${ }^{56}$ should be integrated. After Swinburne's thesis ${ }^{57}$, the discussion about Atonement was particularly intense ${ }^{58}$. To prevent the death of Christ on the cross from being a simple historical representation of eternal events which occurred in God (Hegelian position), then, we can outline: (b.1) a testimonial-prophetic significance (historical immolation): Jesus believed so much in his message that he carried it out in full; (b.2) ontological-regal significance (historical immolation as image of EI): the man made capable of justice, as emancipated (eternally and historically) from original sin; (b.3) the priestly-sacrificial meaning (historical immolation and EI): the man would be inevitably damned, but God decides to forget a large number of his sins.

Point (b.1) means that God died on the cross in order to affirm the freedom of man and release him from every slaveries. The free life of Jesus is a set of gestures - that irritated the "big powers" of his day - that lead him to the cross. Prophets' admonitions (against sacrifices and in favour of a religious reform) had not been effective in breaking the ethnocentric and religious logics (overtaken by Jesus): someone was needed who would select, embody and accomplish all of them. Only Jesus' action - his life affirmed in his death - is the appropriate one which could allow man to understand this message ${ }^{59}$ : this is testified by the human history, who, only as a result of that event has become able, over the centuries, to take steps towards a complete humanism ${ }^{60}$.

Jesus died, therefore, to testify that what he said \thought was true: every person has an infinite dignity, which is greater than "the Sabbath", and which is above the laws of purity, the alleged "truth", the oppressive powers of Caesars, oppressive powers of "the Popes" of all time, oppressive powers of the devil (that is, of all slaveries: money, power, sex, success, envy, racism, egoism...), above all religious and civil

53 «God's pre-eternal counsel or plan concerning the creation of the world necessarily includes the counsel concerning its salvation, that is, concerning the unification of creation with God [...]. Not only the fall that occurred but also the very changeability of the world and, in the final analysis, its creatureliness separate the world from God by an insurmountable distance, which can be overcome only by God, not by man. This constitutes the general foundation for the Incarnation as the manifestation of God's love for the world. If the creation of the world is already a work of God's sacrificial love [...] then the Incarnation is God's sacrificial love that involves the humiliation of Divinity, condescending to the level of hypostatic union with man. But this sacrificial love of God for the world is the pre-eternal foundation of the Incarnation, which is thus the second and concluding act of the creation of the world. In this sense, the Logos is the Lamb of God sacrificed before the creation of the world. [...] The idea of the redemption is thus indissolubly linked with that of the creation, and in a certain sense they are ontologically identicali (Bulgakov, 2008, 413-14). 54 Also Gamberini $(2007,142-43)$ seems to claim a connection between everlasting incarnation and eternal immolation.

55 Quinn (1990); Stump (1990). The doctrine of Atonement is deeply intertwined with the doctrine of Grace, and the Thomistic position can be interpreted in very different ways, such as the dispute de Auxiliis has revealed (Freddoso, 1988). The Catholic position has also reached, today, a rather precarious balance (see: Joint Declaration on the Doctrine of Justification). In the end we place ourselves, mysteriously, between Predestinationism and Pelagianism (Stump, 1988).

56 A different classification of the Doctrine of Atonement (Classical - Anselmian - Reformation - Moral-influence theories) in Wolf (2005): «There is no single New Testament doctrine of the Atonement [...]Tradition has tried to decide what parts of this picture should be taken literally and what parts metaphorically and has developed extended rationales, added new images according to the conditions of different eras and cultures, and established cross-relationships with other Christian doctrines [...] Few doctrines of Christian faith have produced more theories than the doctrine of atonement;; also: Murray and Rea (2016). Recently, King (2015) has discussed the 'perfection account', according to which, Christ perfects us when we participate in His sacrifice (in a perfect love life). He uproots the force of temptation.

${ }^{57}$ Stump (1994); McNaughton (1992); Aspenson (1996). According to Swinburne (2013, 1989, 1988), if a third person’s reparation is plausible, and if the human race is not in a good position to atone for sins, then Jesus is the best candidate to atone for man's sin: God (the Son) gives to God (the father) what is more valuable to the world (the perfect life of God the Son). With our repentance we participate in Christ's sacrifice. The cross is convenient, but not necessary.

${ }^{58}$ Layman (2016); Crisp (2009); Chalke (2008); Finlan (2007, 2005); Stott (2006); Hill and James (2004); Davis, Kendall, and O'Collins (2004); Cross (2001); Lewis (1997); Jensen (1993); Sykes (1991); Gunton (1988); Packer (1974). About Schleiermacher, Barth and Aulén's interpretation: S. Zahl (2013).

${ }^{59}$ It remains uncertain that Christ was the only "way" thanks to which God could communicate certain truths (the resurrection, the redemption of sins). Furthermore, there are good reasons to think that Christ was the best candidate for this holistic-task (Swinburne, 2011, 130-33), even if this reasoning is based on the faith about resurrection and miracles.

${ }^{60}$ Bulgakov believes the interpretation of the dead on the cross as "dying for an ideal" to be reductive; in my opinion, however, must be evaluated the total incommensurability of the ideal (message) of Christ with every other human testimony in favor of human freedom. 
apartheid: any system that does not care for the person (in this, surely, the Cross is a political event (Fox, 1983) that we have not yet sufficiently understood in all its aspects). No man, in no time, has ever brought to fulfillment his preaching and his gestures until such a profound and radical revolution - comprehensive, total, integrated ${ }^{61}$ - of mentality and customs (Christ was aware of this: Lk 12:49-53): only a God could choose and implement a finite number of gestures that means an infinite and universal spiritual revolution.

In order to testify this revolution, it was necessary, for Jesus, to "blaspheme" twice: a religious blasphemy (against the precepts of the Law and the mechanism of compensation and of the victim, the cultural deviances, making Himself the Son of God, that is, the unique final witness) and a secular blasphemy (against the oppressive powers). Only God can blaspheme himself, break into the reality that has misrepresented His image and, in doing so, correct it with a living, emblematic new image: Jesus.

Then, if Jesus blasphemed, if all blasphemies deserved death (in the past religious order that favours the law over the person), and if Jesus could never take back these oaths, then we understand why "testifying in full" necessarily involved the death on the cross. Christ dies on the cross to testify the extreme consequence to which a deadly mentality may lead, a mentality which sacrifices the person for political or religious power, or for a supposed absolute 'truth'. The Innocent just dies on the cross in the hope of being the last one to die this way: only an Incarnate God can do this, because He knows he is dying for the right purpose, He is dying for the 'absolute truth' about human beings - the dignity of humans - and then for all human beings.

There has been considerable discussion about the meaning of (b.2). What about (b.3)? To understand the possible meaning of the EI we could take a look at the Catholic liturgy: according to current doctrine, the Lamb's sacrifice on the cross, together with Incarnation, leads to eternity; if this is true, in some way it had "to be there" before. The Divine Liturgy also implies that there is full identity between the sacrifice of the cross and its sacramental renewal in the Mass; every time we celebrate the memorial of the sacrifice the work of our redemption is accomplished. It is the New Testament, for that matter, which testifies the existence of a heavenly worship of the Lamb: entering heaven as a priest, Christ became a minister of the true sanctuary, the "High Priest" after the order of Melchizedek (He 6: 20) ${ }^{62}$. Jesus is the man who, through his vicarious sacrifice, causes our sins to not be imputed to us, and thus, saves us and makes us free. It is Jesus who reveals to man that God is merciful, and he has decided to forgive men their sins (Col 2: 12-14). The sacrifice of the Cross which exists in every Mass corresponds to the eternal liturgy that, always and forever, occurs in heaven ${ }^{63}$. But if such a liturgy has a characteristic of redemption, then the atoning sacrifice must have been eternal, is wanted and implemented eternally by God ${ }^{64}$ and then deployed in history at the right time. The Son as eternal priest makes the offering of his person to the Father: this is the "metaphysical foundation" of every sacrifice ${ }^{65}$.

There is therefore a structural connection: God's kenotic nature actually corresponds to the liberation that Christ has shown on the cross, which is to reveal to man that freedom, which is the intrinsic characteristic which is common both to God and man. The kenosis implies, from the moral point of view, the ability to forgive and self-forgive, then accept your own limits. Those who have this ability to forget, have a harmonious relationship with power, religion and diversity, and they are able to attach the right measure of importance to each person's dignity. The kenosis is (in some way) the essence of God and should become the essence, the achievement, of humankind.

\footnotetext{
${ }^{61}$ The extent of this spiritual, religious and social revolution started by Jesus is clearer today, thanks to the exegetical and historian studies. It is plausible, therefore, that we can develop an understanding of the event of the cross which may, in part, differ from the medieval doctrines.

62 «This priesthood of Melchisedec is characterized, first of all, by the fact that it is instituted directly by God and is not temporal but eternal» (Bulgakov, 2008, 341).

${ }_{63}$ «The Lamb slain from the foundation of the world» (Rev 13:8). This Bible's verse is not very easy to translate, but is the basis for the interpretations of Atonement.

${ }^{64}$ «There arises here a new question: [...] Does the redemption continue in time after having once been accomplished supratemporally and for all times on the cross? [...] But in this case how should one understand this empirical and as if new burdening of Christ with our sins? There is nothing ontologically new here, because these sins, assumed and redeemed supratemporally, are in their entirety accomplished in an equivalent manner, empirically, in time, in which the content of the supratemporal is thus disclosed: unity in multiplicity and vice versa» (Bulgakov, 2008, 359).

${ }^{65}$ Hani (1999, 26); Lodi (1981, 24-35; on the nature of Eucharistic celebration, 266-267); Boselli (2011).
} 
Clearly, the interpretation of the Cross that we have given here, does not eliminate the other theories of Atonement, but it adds to them as another possible meaning. It would be interesting to explore the possibility that the Eternal Immolation is not only what makes the removal of the fault possible, but also what makes possible the (impossible ${ }^{60}$ ) cancellation of $\sin$.

\subsection{What Eternal Immolation is not}

EI is - evidently - a 'work in progress' hypothesis. But by analyzing the objections to it, we will also clarify the concept, while hoping to be faithful enough to Bulgakov's intuition.

Objection_1. If there is necessity in the acts of kenosis (intra-Trinitarian, creative, redemptive) the world is an emanation of the first kenosis. The theological tradition teaches that the creative act, even kenotic, and the Trinitarian kenosis, were two "free" acts of God: and the Christological-redemptive kenosis (incarnation and the cross) follow the creative act freely. This is a position of faith, but philosophically we have no way of confirming whether each of them is a necessary or a free act. Also because, as we well know, in God necessity and freedom coincide, they are completely useless concepts. The three kenoses are eternal, using a classical theistic concept, even if their explanations in history come at a later date. If we accept that this classical position - although obscure - is valid, it can be effectively used to justify the ulteriority of the 'three kenoses doctrine': they are, on the one hand, simultaneous and eternal (if we accentuate divine eternity, simplicity and necessity and the eternal co-ordination between divine intellect and will), but on the other hand, are distinguishable and not necessary (if we emphasise God's free willingness to put the last two kenoses in place).

Objection_2. Eternal Immolation is a way of affirming the suffering in God. My interpretation is not that $\mathrm{EI}$ is a way of affirming an eternal suffering in God ${ }^{67}$. EI is (on an ontological level) the reciprocal gift, selfemptying, of the Trinitarian persons and (morally) the prior decision by God to take the sin of the world upon Himself, and thus to expiate it and forgive it, because He is a co-author of that sin. It does not mean that God is eternally dying, because the eternal sacrifice in God does not have the character of human suffering (like torture), as the suffering of Christ on the cross may be considered. EI does not add to, or detract from, the situation of philosophical and theological impasse in the attempt to imagine a kind of passibility in God.

Objection_3. The Eternal Immolation is a form of apocatastasi ${ }^{68}$. Surely we must be vigilant in preventing EI from turning into a veiled form of apocatastasis. But let me note down two considerations: (1) Apocatastasis has been a thorn in the side of Christian eschatology from its very beginning, because although it is anathematized - it follows a certain linearity according to some theistic assumptions such as the eternity and the providence of God, the universal sacrifice of Christ, the salvific will and mercy of God. Perhaps, in this case, to refute apocatastasis, we have to surrender to the mystery of the doctrine of God ${ }^{69}$. (2) EI doctrine states that, if the sacrifice of Christ was necessary for the forgiveness of sins, and this sacrifice had already been planned by God, in some ways, that sacrifice had to already be present in God.

\footnotetext{
${ }^{66}$ As we know, once we have committed a sin, it may not be "deleted", since it is an event that has happened in the past (it has become accidentally necessary). To delete it would be unfair. Yet, the mystery of atonement says that, by God's forgiveness, sin is totally deleted, as if it had never happened. We have never tried to penetrate this vast mystery enough!

${ }^{67} \mathrm{In}$ Bulgakov there is no Patripassianism: the divine persons are suffering on the cross, but each in his own way.

${ }^{68}$ Kenotic theology «seem to blur the lines between justification and santification» (Garrett, 2013, 84).

${ }^{69}$ Mancuso $(2007,267-76)$ shows how difficult it is to choose (from Scripture and rational speculation) between apocatastasis, Hell's eternity or the annihilation of wicked souls, claiming that the contradiction between the great mercy of God and the invincible wickedness of the wicked souls remains unresolved. From a systematic point of view, Castellucci (2010, 369-382) categorically rejects apocatastasis (because it would make the human freedom a game) and annihilation (because it excessively underlines human freedom), and then - while acknowledging that Hell appears absurd - he supports the official view of the Church, and finds it more coherent to the position "hope for all" (cleansed of the stereotypes that it is wrapped up in), defended among others, by Balthasar, Przywara, de Lubac, Blondel, Ratzinger, Kasper, Greshake, Guardini, Rahner. The position proposed in this paper is similar to this latter option.
} 
This is not an apocatastasis ${ }^{70}$, but rather a justification of universal predestination to salvation ${ }^{71}$. Taking into account Barth's thinking ${ }^{72}$, believing in predestination means believing the non-disapproval of man. Man is freed from condemnation and this happens by the work of God himself (for this paragraph: Barth, 2004). If we accept the distinction between uncreated and created grace, objective and subjective grace, or sufficient and efficacious grace, we might say that EI corresponds to the first one in each pair: (1) the uncreated-objective-sufficient grace is the grace that is given to men by God and corresponds to the universal salvific will of God. This is the grace-election-predestination described by Barth (Rahner, 1965a, 132); (2) the grace of God is created-subjective-effective when, through circumstances, man accepts the grace of God and works under its effect. EI is the justification, because it redeems the original sin (always and for everyone) as the sin of God, and makes the remission of personal sins potential (always and for everyone). The hypothesis of EI adds almost nothing, doctrinally speaking, but harmonizes the data of faith by assuming an internal event in the life of God that is redemptive besides being ontological. EI also tells us that God will be merciful because He is aware of His 'primordial sin', which impacts on His creatures. But also makes way for the possibility that some human sins are in fact personal, wanted and sought, and therefore wicked and unpardonable. Only God knows and can evaluate them ${ }^{73}$, but this is enough to prevent EI from being an automatic form of apocatastasis ${ }^{74}$.

Therefore, we are justified (Christ took the sin of the world upon himself), but we are not automatically forgiven (sanctified). The grace that descends from EI appertains to the transcendental, the condition in which we are immersed. Any imperfect human compensations (like corporal and spiritual 'works of mercy', sacraments, regret, and so on) are completed by the perfect sacrifice of Christ, which is the manifestation of the eternal choice of God to help man in this "impossible work" of compensation. In "taking upon Himself the sin" Christ accomplishes in perfection the shift of sin \blame from man to God, affirming that God does not consider himself to be innocent, but "takes man's sin upon Himself” because it was with Him from the beginning ${ }^{75}$.

\footnotetext{
${ }^{70} \mathrm{It}$ is also discussed by Leibniz (1952).

${ }^{71}$ «Man is a creature of God; in virtue of his creatureliness he contains relativity or changeability, which includes the possibility of sin. This possibility is a constantly threatening reality that cannot be overcome by the powers of the creature alone. The Creator Himself takes it upon Himself to overcome this possibility: He takes it upon Himself to overcome not only sin but even creatureliness itself. With this He concludes His creation and thereby justifies the act of creation. If not for this divine action, creation would inevitably be imperfect in virtue of its origination out of nothing and thus in virtue of the limitedness and changeability of creaturely freedom. God cannot abandon the world - which, although it is perfect in the initial state of its creation ("it was good"), has in itself the inevitable ontological imperfection of creatureliness and the resulting incompleteness — to its own fate (as the Deists teach)» (Bulgakov, 2008, 345).

72 According to Küng (2004), Barth's theory is compatible with Catholic thinking on grace.

${ }^{73}$ Evaluating human actions is complicated; we have to consider intentions, circumstances, cognitive defects, structural educational deficiencies, psychological, social and cultural dynamics, environmental conditions, the conditioning of biographical history, misjudgments, unhealthy relationships, conflicts of values, the range (which increases considerably over a period of time) of intentional and unintentional consequences; then, a judgment (balanced, reliable and indisputable) of an action requires a substantially omniscient view. Human justice is entitled to proceed with reasonable simplifications, but divine (perfect) justice obviously not. So, we do not know how God will judge us, "which and how many" sins will be forgiven, except for a vague approximation which is our religious set of precepts. Perhaps Christ, affirming God's mercy, wants to emphasize this irreducibility of divine justice to any human parameter, and then release man from the diabolical temptation of becoming the judge of other humans' salvation instead of God.

${ }_{74}$ «That is why human sins, as possibilities, can be [...] redemptively assimilated and livingly overcome by the Lamb of God who takes upon Himself the sins of the world, that is, the works of rebellious and infirm creaturely freedom. [...] It is this knowledge of the power and profundity of human sin in general with all its possibilities that constitutes the foundation of the redemptive selfidentification of the Lamb of God with the fallen human race with all its sins in the past, the present, and the future. Thus, the redemption does not revoke creaturely freedom in its actual limits $[\ldots]$ because it presupposes human freedom, which is free to accept it or not accept it» (Bulgakov, 2008, 349-50).

75 «Christ's taking of sin upon Himself would have been docetic if it were not accompanied by all its consequences, that is, by God's anger and by His abandonment of Christ. [...] Once it is suffered to the end and redeemed, sin is no longer a barrier between God and the sinner; it is as if it does not exist. God's justice received the possibility of pardoning the sinner by a gift of grace (gratia gratis data), and God's anger does not weigh on the sinner if he himself desires to accept this gift [...].The sin He takes upon Himself by virtue of love is no longer a sin alien to Him; it is now His own sin, although not committed but only accepted by Him. Such is the power of identification that is manifested in the redemption» (Bulgakov, 2008, 361-62).
} 
Objection_4. Eternal Immolation is only a theological notion, not philosophical. EI concerns various themes, and some of its contents are completely philosophical. Admitting this, however, implies a confession that some Trinitarian notions (like eternal generation, kenosis, the subsistent relations) have a philosophical significance, and are a speculative necessity of philosophy, in its investigation of divine nature (Migliorini, 2017). If, then, we achieve philosophically a 'personal God', and if a 'metaphysics of theism' has a consistency, this could imply a philosophical notion of EI which is detached from the positive manifestation (Revelation, theological) of Christ on the cross, but which is attached to a Trinitarian vision of God of a philosophical nature ${ }^{76}$.

Objection_5. Eternal Immolation does not solve the Problem of Evil. There is no doubt that it is this is quite true. EI does not console us, or "explain" much. We have already repeatedly stated that we consider the Problem of Evil basically to be "pending". This means that "solutions" or "explanations" are precluded from the outset. EI does not try to solve anything, but tries to be just a little 'more consistent' than other theories, which are unable to rationalize completely. Here, by "consistency", I mean precisely the need for a concept such as EI if we accept certain premises (e.g. the ontology of freedom, kenosis, incomprehensibility of original sin and Grace, of human freedom etc.). The consistency arises from the coordination, in a concept, of a series of accepted premises.

\section{Conclusion: Ontology of freedom, Trinitarian ontology and Eternal Immolation are a "good" frame for the 'logic-of-love defense'?}

Analyzing the theological positions of Open Theism we have seen that a great emphasis is put on the logic-of-love, which implies that 'God is love', in the sense that He behaves in a loving way, but also that this "behavior" must correspond to the divine essence (which coincides with the action of God). The best model, then, is the Trinity, in which the divine essence is the mutual self-giving of three divine persons, in a free eternal kenosis act (and thus Generation and Spiration) which creates ad extra, and lovingly takes care of the world ${ }^{77}$. «God is love», then, becomes a logic-of-love defense (Lld) with regard to the Problem of Evil, which finds a place in the Trinitarian speculation. There is thus a kind of double implication between Lld and the Trinity. The Lld, in addition, is based on the assumption that between God and man there is an "equal" relationship between two "people", and so also involves the free will defense (Fwd). What we have gradually observed, however, is that neither the Fwd nor Lld are sufficient to explain the mystery of evil.

What the Lld says is that God decided to create due to an abundance of love and by making a free choice; but this is the crucial point: the consideration of the personal mystery of evil would lead us to conclude that God could avoid creating; although we don't know if the amount of evil in the world is more than the amount of good, when the life of a person - with his infinite dignity - is sacrificed, evil appears to be infinite, incalculable. Also accepting this incomprehensible creative choice ${ }^{78}$, however, we fail to understand why God does not intervene to limit some bad events; of course, in intervening, God would radically alter the original terms of his project, but in certain situations this does not seem a sufficient justification for non-intervention.

The Lld, therefore, integrates and contains the Fwd and Aquinas-Leibniz's theodicy, but it must also recognize its failure to explain the "personal mystery of evil'; in order to "solve" this "problem", it must be linked with the mysterious creative choice of God, mysterious precisely because free. If this freedom even though analogical - is distinct from necessity, we have to 'blend' in some way the Lld and the Trinitarian speculation also with the ontology of freedom, which, implying a form of kenosis, is best suited to being a Trinitarian ontology. It appears that only a truly free being (God, not in the compatibilistic sense) can create a free being (man, in the libertarian sense). A necessary being (God) can only create a necessary being (a puppet): without an ontology of freedom which interprets in a libertarian sense the freedom of

\footnotetext{
${ }^{76}$ Migliorini (2014b); Cacciari (1990).

${ }^{77}$ We might wonder if this Trinitarian approach can overcome the objections raised against the logic of love by Howard-Snyder (Howard-Snyder and Howard-Snyder, 1993, 185-192). Probably yes, even if the outcome is radically apophatic.

${ }^{78}$ That a good God should create, and that He should create other personal beings endowed with the freedom of indifference are the basis of the logic of love defense... but it is a defense that relies on such a large mystery!
} 
God, the logic of love defense is crippled ${ }^{79}$. The ontology of freedom, however, needs the Trinitarian theology in order to integrate the kenotic moment (of Nothingness, or of Evil) in the essence of God.

Finally, we have seen that the sum of all these schools of thought seems to imply EI: the Trinitarian hypothesis postulates a kenotic theology and then EI in its various interpretations. The EI is not due to the historical sin of Adam, but is intrinsic to the love of God as Creator, and this seems perfectly in line with the contemporary theological speculations on the myth of Genesis, which tend to place greater emphasis on the co-implication of creation and redemption. If we accept that 'God is love', and love could not notcreate, and could not create-not-so (this world) ${ }^{80}$, then He must create and redeem at the same time (the theistic hypothesis, therefore, implies EI).

Is the notion of EI a useful way of thinking about Original Sin, Grace, Providence, and of "solving" the Problem of Evil? We have given the answer several times: neither the Lld, nor EI can be of much assistance here. EI does not give us a rational solution, it gives us at most a hope, but confirms that our dismay of evil is justified, until the rebellion. Mysteriously, God is not innocent, and pays for us. Is this a consolation? Absolutely not, Dostoevskij would say, rightly: the "Christological perspective" - the mysterious solidarity of God with our sufferings - does not reduce the sufferings, nor their absurdity. Our anger remains, and we inevitably 'blaspheme' God, just like Job did in the Bible. Maybe, EI reveals to us that God is aware - justifies and forgives - this "unavoidable" blasphemy.

I have tried to demonstrate how the idea of EI (developed by Bulgakov) can be considered to be a consequence of - if not already present - recent speculations, such as those of the OT, Moltmann, Barth, the kenotic theology, Pareyson. Its validity stands or falls when we accept that these schools of thought have actually identified some unresolved points in Christian doctrine, theistic or theological. I have tried to explain how all these speculations tend to converge on some basic assumptions: all of them seem to assume one or several forms of divine kenosis, a more or less explicit form of ontology of freedom, and a kind of logic-of-love defense, which are closely linked to a libertarian vision of human free will, and the acknowledgement of the unresolved mystery of evil, because of the existence of pure evil and the personal mystery of evil. If we accept these points, then the EI doctrine can acquire its relevance and its place within the overall architecture. However, it seems clear that, at this stage of the discussion, the Trinitarian perspective and the logic-of-love defense do not help to "solve" the Problem of Evil, if by "resolving" we mean a rational response in which each element stays in its logical and coherent position.

\section{Appendix 1. Sketch of a scheme of Eternal Immolation}

\footnotetext{
${ }^{79}$ As rightly pointed out by Howard-Snyder (1993, 185-92) by the existence of "love" in God in unequivocal terms, a form of divine freedom must be assumed which is sufficiently comparable to human free will.

80 «The very life of love in God [...] contemplates a "sacrifice" of joy and glory, when the Son offers himself totally to the Father, also in preparation for the Self-sacrifice for the salvation of creation» (Coda, 1993, 142).
} 


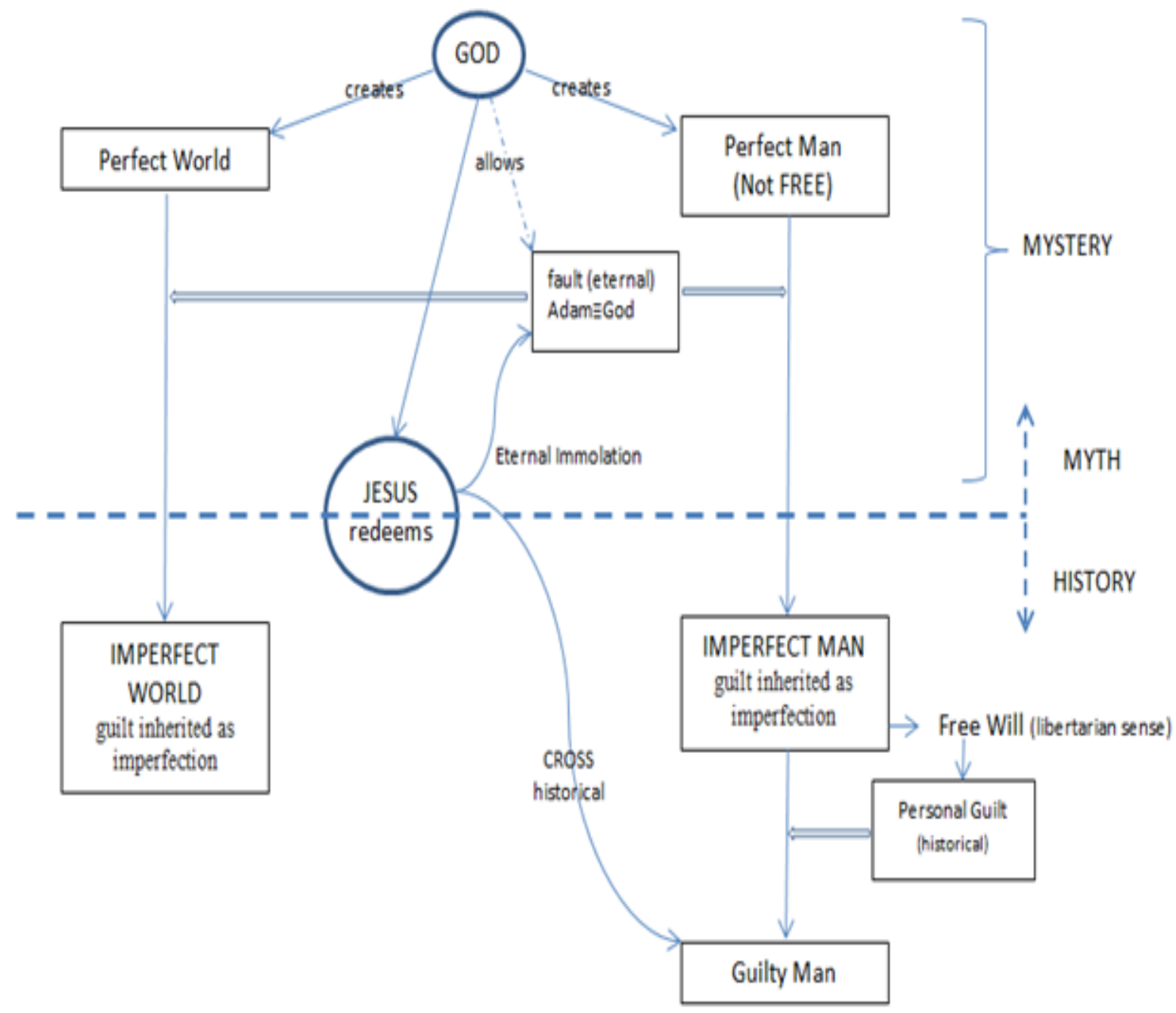

\section{References}

Alison, J. (2009). Le peché originel à la lumière de la Résurrection. Paris: Cerf.

Alston, W.P. (2002). "Substance and the Trinity". In Davis, S.T. \& Kendall, D., The Trinity. Oxford: Oxford University Press, 179-201.

Aspenson, S.S. (1996). "Swinburne on Atonement". Religious Studies, 32, 187-204.

Balthasar, H. U. von (1971). "Mysterium Paschale". In Mysterium Salutis. vol.6, Brescia: Queriniana.

Barth, K. (2004). "The Doctrine of divine Election". In Church Dogmatics. vol. II/2, London: T\&T Clark.

Basinger, D. (1991). "Process Theism Versus Free-Will Theism: a response to Griffin". Process Studies, 20, 204-220.

Bianchi, E. (1990). Adamo, dove sei?. Magnano: Qiqajon.

Bishop, J. \& Perszyk, K. (2011). "The normatively relativised logical argument from evil”. International Journal for Philosophy of Religion, 70, 109-126.

Boselli, G. (2011). Il senso spirituale della liturgia. Magnano: Qiqajon.

Bouyer, L. (1978). The Eternal Son: a theology of the Word of God and Christology. Our Sunday Visitor.

Bouyer, L. (1988). Cosmos: The World and the Glory of God. Petersham: St. Bede's.

Brito, E. (2006). "Kenosi”. In Lacoste, J-Y. \& Coda, P., (eds.). Dizionario critico di teologia. Roma: Borla, $722-724$.

Bulgakov, S. N. (2008). The Lamb of God. Gran Rapids: Eerdmans. 
Businelli, G. (1943). Il dubbio di Dante sulla predestinazione. Roma: Acta Pont. Academiae Romanae S. Thomae Aq. et religionis catholicae, vol. 8.

Cacciari, M. (1990). Dell'Inizio. Milano: Adelphi.

Cacciari, M. (1996). Trinità per atei. Forte, B. (ed), Milano: Cortina.

Castellucci, E. (2010). La vita trasformata, saggio di escatologia. Assisi: Cittadella.

Cerasi, E. (2006). “Teologia dialettica". In Cerasi, E., Il paradosso della grazia. La teo-antropologia di Karl Barth. Roma: Città Nuova.

Chalke, S., et al. (2008). The Atonement Debate: Papers from the London Symposium on the Theology of the Atonement. Grand Rapids: Zondervan.

Charamsa, K. O. (2002). L'Immutabilità di Dio. L'insegnamento di S. Tommaso d'Aquino nei suoi sviluppi presso i commentatori scolastici. Roma: Pontificia Università Gregoriana.

Charamsa, K. O. (2003). Davvero Dio soffre? La tradizione e l'insegnamento di S. Tommaso, Bologna: Edizioni Studio Domenicano.

Chiereghin, F. (1991). Il problema della libertà in Kant. Trento: Pubblicazioni di Verifiche, vol. 17.

Ciancio, C. (1989). Schelling. Pensare l'assente. In Ciancio, C. (ed). In lotta con l'angelo. La filosofia negli ultimi due secoli di fronte al cristianesimo. Torino: SEI.

Ciancio, C. (2006). Del male e di Dio. Brescia: Morcelliana.

Ciancio, C. (2009). "Blaise Pascal". In Riconda, G., \& Ravera, M. (eds). Il peccato originale nel pensiero moderno. Brescia: Morcelliana, 239-254.

Clayton, P. (2005). “Kenotic Trinitarian Panentheism”. Dialog, 44, 250-255.

Coda, P. (1987). Il negativo e la Trinità. Ipotesi su Hegel. Roma: Città Nuova.

Coda, P. (1993). Dio Uno e Trino. Milano: San Paolo.

Coda, P. (1998). L’Altro di Dio. Rivelazione e kenosi in S. Bulgakov. Roma: Città Nuova.

Coda, P. (2003). Il Logos e il Nulla. Trinità religioni mistica. Roma: Città Nuova.

Coda, P. (2011). Dalla Trinità. L'avvento di Dio tra storia e profezia. Roma: Città Nuova.

Coda, P. (2014). "Sergej N. Bulgakov (1871-1944)". Credere Oggi, http://www.credereoggi.it

Coleman, R.J. (2013). "Save Original Sin from the Secularists". Theology Today, 70, 394-406.

Creel, R. (2010). "Immutability and Impassibility". In Taliaferro C., Draper, P., \& Quinn, P.L. (eds.). A companion to Philosophy of Religion. Oxford: Blackwell, 322-328.

Crisp, O. (2009). "Original Sin and Atonement". In Flint, T. \& Rea, M. (eds.). The Oxford Handbook of Philosophical Theology. Oxford: Oxford University Press.

Cross, R. (2001). "Atonement without Satisfaction". In Flint, T. \& Rea, M. (eds.). The Oxford Handbook of Philosophical Theology. Oxford: Oxford University Press, 328-347.

Dante Alighieri, (2014). The Divine Comedy. London: Penguin.

Davies, B. (1993). An introduction to the Philosophy of Religion. Oxford: Oxford University Press.

Davis, S., Kendall, D. \& O’Collins, G. (2004). The Redemption. Oxford: Oxford University Press.

Davis, S., (2006). "Is kenotic theology orthodox?". In Christian Philosophical Theism. Oxford Scholarship, Oxford.

De Caro, M. (2004). Il libero arbitrio, un'introduzione. Roma-Bari: Laterza.

Di Napoli, R. (2000). Il problema del male nella filosofia di Luigi Pareyson. Roma: Gregorian University Press.

Donà, M. (2008). L'aporia del fondamento. Milano: Mimesis.

Dostoevskij, F. (2003). The Brothers Karamazov. London: Penguin.

Durwell, F.X. (1999). Christ, Humankind and Death. Paris: Mediaspaul.

Fabris, R. (2014). Il peccato originale come problema filosofico. Brescia: Morcelliana.

Ferretti, G. (2009). "Immanuel Kant". In Riconda, G., \& Ravera, M. (eds). Il peccato originale nel pensiero moderno. Brescia: Morcelliana, 543-567.

Ferrier, F. (1966). Il problema del male pietra di scandalo. Milano: Paoline.

Finlan, S. (2005). Problems with Atonement: The Origins of, and Controversy About, the Atonement Doctrine. Collegeville: Liturgical Press.

Finlan, S. (2007). Options on Atonement in Christian Thought. Collegeville: Liturgical Press.

Fiorini, P.P. (2000). "Mysterium Iniquitatis: tra male radicale e male originario". In Brena, G. L. (ed). Mysterium iniquitatis. Roma: Gregoriana, 60-81.

Fox, M. (1983). Original Blessing. Rochester: Inner Tradition Bear \& Company.

Freddoso, A. J. (1988). "Introduction". In Molina, L. De, On divine foreknowledge. Part IV of the Concordia. Ithaca: Cornell University Press. 
Fremstedal, R. (2014). Kierkegaard and Kant on Radical Evil and the Highest Good: Virtue, Happiness, and the Kingdom of God. New York: Palgrave Macmillan.

Galeazzi, U. (2014). "Introduzione". In Tommaso d'Aquino, Il male e la libertà. Milano: Rizzoli.

Gallaher, B. (2016). Freedom and Necessity in Modern Trinitarian Theology. Oxford: Oxford University Press.

Gamberini, P. (2007). “Trinità e umanità di Dio". In Coda, P., \& Donà, M. (eds.). Dio-Trinità tra filosofi e teologi. Milano: Bompiani, 125-147.

Garrett, S. M. (2013). God's Beauty-in-act. Eugene: Wips and Stocks.

Gavrilyuk, P.L. (2005). “The Kenotic theology of Sergius Bulgakov”. Scottish Journal of Theology, 53, 251 269.

Geach, P. (1977). Providence and Evil. Cambridge: Cambridge University Press.

Gerl-Falkowitz, H.B. (2005). "La storia dell'Etica nel pensiero di Guardini ovvero la tensione tra natura e soprannatura". In Marcolungo, F.L., \& Zucal, S. (eds). L'etica di Romano Guardini. Brescia: Morcelliana, 11-40.

Gevaert, J. (1992). Il problema dell'uomo. Introduzione all'antropologia filosofica. Torino: Elledici.

Gibellini, R. (2016). "Ripensare il peccato originale”. Rassegna di Teologia, 57, 135-144.

Gomarasca, P. (2009). "Antonio Rosmini”. In Riconda, G., \& Ravera, M. (eds). Il peccato originale nel pensiero moderno. Brescia: Morcelliana, 753-769.

Gorodetzky, N. (1938). The Humiliated Christ in Modern Russian Thought. London: Society for promoting Christian Knowledge.

Grossi, V., Ladaria, L. F., Lécrivain, Ph., \& Sesboüé, B. (1997). Storia dei dogmi. L’uomo e la sua salvezza. Milano: Piemme.

Gunton, C. (1988). The Actuality of Atonement. London: T\&T Clark.

Hani, J. (1999). La divina liturgia: considerazioni sulla messa. Roma: Arkeios.

Hauke, M. (2011). "L'immutabilità e l'impassibilità di Dio secondo i Padri della Chiesa". Rivista Teologica di Lugano, 16, 169-183.

Hick, J. (1967). "The problem of Evil". In P. Edwards (ed.). Encyclopedia of Philosophy. Detroit: Gale (2005), 471-477.

Hill, C., \& James, F. (2004). The Glory of the Atonement. Downers Grove: Inter-Varsity Press.

Howard-Snyder, D., \& Howard-Snyder, F. D., (1993). "The Christian Theodicist's appeal to love". Religious Studies, 29, 185-192.

Hume, D. (2007). Dialogues Concerning Natural Religion. Cambridge: Cambridge University Press.

Inwagen, P. Van (1982). "The incompatibility of free will and determinism". In Free Will. Oxford Readings in Philosophy. Oxford: Oxford University Press.

Inwagen, P. van (2006). The Problem of Evil. Oxford: Oxford University Press.

Jensen, P. (1993). "Forgiveness and Atonement". Scottish Journal of Theology, 46, 141-160.

Jonas, H. (1987). "The Concept of God after Auschwitz: a Jewish Voice". The Journal of Religion, 67, 113.

Jorgensen, L. M., \& Newlands, S. (2014). New Essays on Leibniz's Theodicy. Oxford: Oxford University Press.

Kant, I. (2003). Critique of pure reason. Mineola: Dover Publ.

Kearney, R. (2011). Anatheism: returning to God after God. New York: Columbia University Press.

King, R. (2015). "Atonement and the completed perfection of human nature". International Journal for Philosophy and Theology, 76, 69-84.

Kretzmann, N. (1997). The Metaphysiscs of Theism. Oxford: Clarendon Press.

Küng, H. (1987). The incarnation of God: an introduction to Hegel's theological thought as prolegomena to a future Christology. Edinburgh: T. \& T. Clark.

Küng, H. (2004). Justification: The Doctrine of Karl Barth and a Catholic Reflection. Louisville: Westminster John Knox Press.

Layman, C.S. (ed.), (2016). Philosophical Approaches to Atonement, Incarnation and the Trinity. Dordrecht: Spinger.

Leftow, B. (2012). "Immutability". In E.N. Zalta (ed.). The Stanford Encyclopedia of Philosophy. http://plato.stanford.edu.

Leibniz, G. W. von (1952). Theodicy. A. Farrer (ed.), London: Yale University Press.

Lewis, D. (1997). “Do We Believe in Penal Substitution?”. Philosophical Papers, 26, 203-209.

Limone, V. (2013). Inizio e Trinità. Il neoplatonismo giovanneo nell'ultimo Schelling. Pisa: ETS. 
Lodi, E. (1981). La Liturgia della Chiesa. Bologna: Edizioni Dehoniane Bologna.

Lorizio, G. (2006). "Il nome di Dio è Amore. La dimensione teo-logica della carità". In Fisichella, R. (ed.).

Dio è amore. Commento teologico-pastorale a 'Deus Caritas est'. Roma: Lateran University Press.

Mackie, J.L., (1955). "Evil and Omnipotence". Mind, 64, 200-212.

MacTaggart, J. E. (1906). Some Dogma of Religion. London: Arnold.

Mancuso, V. (2007). L'anima e il suo destino. Milano: Cortina.

Mazza, G. (2008). Incarnazione e umanità di Dio. Figure di un'eternità impura. Milano: San Paolo.

Marmodoro, A. \& Hill, J. (2011). The Metaphysics of the Incarnation. Oxford: Oxford University Press.

McCloskey, H.J. (1960). "God and Evil". Philosophical Quarterly, 10, 97-114.

McNaughton, D. (1992). "Reparation and Atonement". Religious Studies, 28, 129-44.

Migliorini, D. (2014a). 'Dall'incompatibilismo di Pike all'Open Theism: il dibattito sull'onniscienza divina nella filosofia analitica della religione". Rivista di Filosofia, 105, 273-288.

Migliorini, D. (2014b). “Trinità per filosofi? Lineamenti di un teismo trinitario”. Studia Patavina, 61, 471 482.

Migliorini, D. (2014c). "Parola e Silenzio, figure di fede e libertà". Vivens Homo, 25, 497-509.

Migliorini, D. (2015a). "L'ockhamismo nel dibattito analitico contemporaneo sull'onniscienza divina. Un bilancio". Laurentianum, 56, 33-86.

Migliorini, D. (2015b). "Prospettive del molinismo nel dibattito contemporaneo sull'onniscienza divina". Verifiche, 44 (1-4), 71-106.

Migliorini, D. (2016a). "La soluzione di Boezio nel dibattito contemporaneo sull'onniscienza divina: un bilancio". Rassegna di Teologia, 57, 15-53.

Migliorini, D. (2016b). "La «soluzione tomistica» nel dibattito analitico contemporaneo sull'onniscienza divina e la libertà umana". Divus Thomas, 119, 359-395.

Migliorini, D. (2017). "Fondamenti di un teismo trinitario". Antonianum, 92, 49-83.

Mitchell, D.W. (1991). Spirituality and Emptiness: The Dynamics of Spiritual Life in Buddhism and Christianity. Mahwah: Paulist Press.

Moltmann, J. (2015). The Crucified God: The Cross of Christ as the Foundation and Criticism of Christian Theology. Minneapolis: Fortress Press.

Moreland, J. P., \& Craig, W. L., (2003). Philosophical Foundations for a Christian Worldview. Downers Grove: Inter-Varsity Press.

Mounier, E. (1950). “Emmanuel Mounier 1905-1950”. Esprit, 12, 1010-1011.

Mühlen, H. (1974). La mutabilità di Dio come orizzonte di una cristologia futura. Brescia: Queriniana.

Murray, M. J., \& Rea, M., (2016). "Philosophy and Christian Theology". In E.N. Zalta (ed.). The Stanford Encyclopedia of Philosophy. http://plato.stanford.edu.

Murray, M. J., \& Greenberg, S. (2016). "Leibniz on the Problem of Evil". In E.N. Zalta (ed.). The Stanford Encyclopedia of Philosophy. http://plato.stanford.edu.

O’Donnell, J. (1995). “The Trinitarian Panentheism of Sergej Bulgakov”. Gregorianum, 76, 31-45.

O’Regan, C. (2011). “The Trinity in Kant, Hegel and Schelling”. In Gilles Emery, G., \& Levering, M. (eds). The Oxford Handbook of the Trinity. Oxford: Oxford University Press, 254-266.

Oppy, G. (2010). “The Evidential Problem of Evil”. In Taliaferro C., Draper, P., \& Quinn, P.L. (eds.). A companion to Philosophy of Religion. Oxford: Blackwell, 500-508.

Packer, J. (1974). "What did the Cross achieve? The logic of penal substitution". Tyndale Bulletin, 25, 345.

Panikkar, R. (1975). The Trinity and the Religious Experience of Man. London \& New York: Orbis.

Papanikolaou, A. (2011). "Contemporary Orthodox Currents on the Trinity". In Gilles Emery, G., \& Levering, M. (eds). The Oxford Handbook of the Trinity, Oxford: Oxford University Press, 328338.

Pareyson, L. (1971). Verità e interpretazione. Milano: Mursia [Truth and Interpretations. (2013) Suny Press].

Pareyson, L. (1995). Ontologia della libertà. Il male e la sofferenza. Torino: Einaudi [excerpts in Existence, Interpretation, Freedom: Selected Writings. (2009), P.D. Bubbio, Davies Group].

Pastrello, M. (2000). "J. Maritain e la sofferenza di Dio: un approfondimento". In Brena, G. L. (ed). Mysterium iniquitatis. Roma: Gregoriana, 261-273.

Pawl, T. (2012). "Divine Immutability". Internet Encyclopedia of Philosophy. www.iep.utm.edu

Peterson, M.L. (2010). “The Logical Problem of Evil”. In Taliaferro C., Draper, P., \& Quinn, P.L. (eds.). A companion to Philosophy of Religion. Oxford: Blackwell, 491-499.

Pike, N. (1963). "Hume on Evil". The Philosophical Review, 72, 180-197. 
Pinnock, C. (1995). The Grace of God and the Will of Man. Minneapolis: Bethany House.

Pinnock, C., Sanders, J., Hasker, W., \& Basinger, D., (1994). The openness of God: a biblical challenge to the traditional understanding of God. Downers Grove: Inter-Varsity Press.

Plantinga, A. (1974a). God, freedom and Evil. Grand Rapids: Eerdmans.

Plantinga, A. (1974b). The nature of necessity. Oxford: Clarendon Press.

Plotinus, (1991). The Enneads. London: Penguin.

Polkinghorne, J. (2001). "Kenotic Creation and Divine Action". In Polkinghorne, J. (ed). The Work of Love: Creations as Kenosis. Grand Rapids: Eerdmans, 102-106.

Quinn, P.L. (1990). “Aquinas on Atonement”. In Feenstra, R.J., \& Plantinga, C. (eds). Trinity, Incarnation and Atonement. Philosophical and Theological Essays. Notre Dame: University of Notre Dame Press, 153-177;

Quinn, P.L. (2010). "Sin and Original Sin”. In Taliaferro C., Draper, P., \& Quinn, P.L. (eds.). A companion to Philosophy of Religion. Oxford: Oxford University Press, 614-621.

Rahner, K. (1965a). "Possibilità di una concezione scolastica della grazia increata". In Saggi di antropologia soprannaturale. Roma: Paoline.

Rahner, K. (1965b). "Rapporto tra natura e grazia". In Saggi di antropologia soprannaturale. Roma: Paoline, 44-77.

Rice, R. (2004). God's Foreknowledge and Man's Free Will. Eugene: Wipf and Stock.

Richard, L. (1982). A kenotic Christology: in the humanity of Jesus the Christ, the compassion of God. New York: University Press of America.

Ricoeur, P. (2007). Evil: a challenge to philosophy and theology. London: Continuum.

Rissler, J. (2015). “Open Theism”. Internet Encyclopedia of Philosophy. www.iep.utm.edu

Roatta, G. (1947). Libero arbitrio, grazia, predestinazione, fondamento unitario della Divina Commedia. Roma: San Paolo.

Rondet, H. (1971). Il peccato originale e la coscienza moderna. Milano: Borla.

Rossi, O. (2000). "Il male e il nulla". In Brena, G. L. (ed). Mysterium iniquitatis. Roma: Gregoriana, 83-96.

Rowe, W. (1986). “The empirical argument from Evil". In Audi, R., \& Wainwright, W.J. (eds). Rationality, Religious Belief and Moral Commitment. Ithaca: Cornell University Press.

Rowe, W. (2001). God and the problem of evil. Malden: Blacwell.

Salamon, J. (2015). "Atheism and Agatheism in the Global Ethical Discourse: Response to Peter Millican and Branden Thornhill-Miller". European Journal for Philosophy of Religion, 7, 197-245.

Sanders, J. (1998). The God Who Risks. Downers Grove: InterVarsity Press.

Sanna, I. (1994). Chiamati per nome, antropologia teologica. Milano: San Paolo.

Sanna, I. (1996). "Una possibile esposizione sistematica del dogma del peccato originale". In A.T.I., Questioni sul peccato originale. Padova: Messaggero, 239-252.

Savino, R. (2000). "Il problema del male nelle Quaestiones disputatae De malo di Tommaso d'Aquino", In Brena, G. L. (ed). Mysterium iniquitatis. Roma: Gregoriana, 97-112.

Scheffczyk, L. (1998). "Immutabilità e libertà di Dio. Approccio teologico sistematico". In Hauke, M., \& Pagani, P., (eds). Eternità e Libertà. Milano: Franco Angeli.

Scheffczyk, L. (2012). La Creazione come apertura alla salvezza. Dottrina della creazione. Città del Vaticano: Lateran University Press.

Serretti, M. (1998). Il mistero della eterna generazione del Figlio attraverso l'opera di Hans Urs von Balthasar. Roma: Pontificia Università Lateranense - Mursia.

Staglianò, A. (2003). "Teologia Trinitaria". In Canobbio, G., \& Coda, P., (ed). La teologia del XX secolo, un bilancio. vol. 2, Roma: Città Nuova, 89-174.

Stott, J. (2006). The Cross of Christ. Downers Grove: Inter-Varsity Press.

Stump, E. (1988). "Atonement According to Aquinas". In Morris, T.V. (ed). Philosophy and the Christiana Faith. Notre Dame: University of Notre Dame Press.

Stump, E. (1990). "Atonement and Justification". In Feenstra, R.J., \& Plantinga, C. (eds). Trinity, Incarnation and Atonement. Philosophical and Theological Essays. Notre Dame: University of Notre Dame Press, 178-209.

Stump, E. (1994). "Richard Swinburne: Responsibility and Atonement". Faith and Philosophy, 11, 321-328.

Stump, E. (2001). “Augustine on free will”. In Stump, E., \& Kretzmann, N. (eds). Cambridge Companion to Augustine. Cambridge: Cambridge University Press.

Stump, E. (2010). Wandering in Darkness: Narrative and the Problem of Suffering. Oxford: Oxford University Press. 
Swinburne, R. (1988). "The Christian Scheme of Salvation". In Morris, T.V. (ed). Philosophy and the Christiana Faith. Notre Dame: University of Notre Dame Press, 15-30.

Swinburne, R. (1989). Responsability and Atonement. Oxford: Oxford University Press.

Swinburne, R. (1998). Providence and the Problem of Evil. Oxford: Oxford University Press.

Swinburne, R. (2011). Was Jesus God?. Oxford: Oxford University Press.

Swinburne, R. (2013). "Responsability, Atonement, Forgiveness". In Moreland, J.P., Meister, Ch., \& Sweiss, K.A. (eds). Debating Christian Theism. Oxford: Oxford University Press, 361-371.

Sykes, S. W. (ed.), (1991). Sacrifice and Redemption: Durham Essays in Theology. Cambridge: Cambridge University Press.

Tomatis, F. (1994). Kenosis del Logos. Ragione e Rivelazione nell'ultimo Schelling. Roma: Città Nuova.

Tomatis, F. (1995). Ontologia del male. L’ermeneutica di Pareyson. Roma: Città Nuova.

Tomatis, F. (1997). Schelling: mysterium Trinitatis. In Coda, P., \& Tapken, A. (eds). La Trinità e il pensare. Roma: Città Nuova.

Tomatis, F. (2003). Pareyson. Vita, filosofia, bibliografia. Brescia: Morcelliana.

Tomatis, F. (2007). Inizio e Parola di Dio. In Coda, P., \& Donà, M. (eds.). Dio-Trinità tra filosofi e teologi. Milano: Bompiani, 95-108.

Toniolo, A. (1995). La Theologia crucis nel contesto della modernità. Il rapporto tra croce e modernità nel pensiero di E. Jüngel, H. U. von Balthasar e G. W. F. Hegel. Milano: Glossa.

Tooley, M. (2015). “The Problem of Evil”. In E.N. Zalta (ed.). The Stanford Encyclopedia of Philosophy. http://plato.stanford.edu.

Ubbiali, S. (1996). "Il peccato originale. L'esistenza dell'uomo e l'aporia del male". In A.T.I., Questioni sul peccato originale. Padova: Messaggero, 9-60.

Vallier, P. (2000). Modern Russian Theology: Bukharev, Soloviev, Bulgakov. Grand Rapids: Eerdmans.

Wainwright, W. (2012). "Concepts of God". In E.N. Zalta (ed.). The Stanford Encyclopedia of Philosophy. http://plato.stanford.edu.

Wolf, W. J. (2005). “Atonement: Christian Concepts”. In Jones, L. (ed.). Encyclopedia of Religion. vol. 1., London: Macmillan, 594-598.

Zahl, S., (2013). “Atonement”. In Adams, N., \& Pattison, G., Ward, G. (eds). The Oxford Handbook of Theology and Modern European Thought. Oxford: Oxford University Press, 633-655.

Zak, L. (2007). "La ricezione della teologia di Bulgakov in Occidente: un capitolo importante della storia della teologia". Reportata, mondodomani.org 